Reactive arthritis

\section{Shigella induced reactive arthritis}

\section{J S Hill Gaston}

\section{A long-haul travel syndrome?}

$\mathrm{S}$ higella infection is the least common of the gastroenteritis-inducing organisms which are associated with reactive arthritis (ReA) in developed countries, reflecting the scarcity of the organism in these environments. A recent thorough survey of Shigella infected subjects in Finland ${ }^{1}$ describes an annual incidence of Shigella induced ReA of only 1.3 per million. This compares with the incidence figures of 46 per million for ReA due to Chlamydia infection, and 50 per million for other enteric pathogens, noted in a survey of the Oslo population. ${ }^{2}$ However, the relevant denominator for Shigella induced ReA is not the population of Finland, but the population visiting distant travel destinations-for example Egypt, India, Thailand, Congo, and Turkey-all countries where the infection was acquired by the Finnish patients. Although these countries, particularly, Turkey, are increasingly common holiday destinations for sunstarved Northern Europeans, well under $5 \%$ of the population visit such countries in any $\mathrm{l}$ year, so the incidence of ReA is more like $30-40$ per million in the exposed population.

\section{SHIGELLA SPECIES}

Of the Shigella species encountered in sunny places, the commonest is $S$ sonnei. This might be considered a source of comfort to the intending B27+ traveller, because $S$ sonnei was at one time considered not to induce ReA. The recent paper from Finland ${ }^{1}$ dispels this idea; S sonnei was the commonest of the Shigellae isolated from patients who developed ReA, and there appeared to be no significant difference in the incidence of ReA following $S$ sonnei and $S$ flexneri infection. Why this difference from previous reports? Although cases of ReA following $S$ sonnei infection were reported as long ago as 1947, and there were additional reports in 1988 (three cases ${ }^{3}$ ) and 2002 (a sexually acquired case $^{4}$ ), two other major reports have been interpreted as exonerating $S$ sonnei in ReA. Simon et al noted two and three cases in two outbreaks of $S$ flexneri infection each involving $\sim 200$ patients, but no case among 99 patients infected with $S$ sonnei. ${ }^{5}$ More strikingly, Kaslow and colleagues found not a single case of ReA among 1970 patients with S sonnei infection in Puerto Rico. ${ }^{6}$ It was argued that additional, undetected pathogens might have had a role in those cases reported as apparently due to $S$ sonnei infection. Thus the conclusion that $S$ sonnei is innocent of inducing ReA seemed reasonable, but additional factors need to be borne in mind.

Firstly, the numbers of cases in the outbreaks described by Simon et al were small, and the $S$ sonnei infected cohort involved children and young adults, a group which seems less susceptible to ReA induced by enteric infection.

\section{"Populations in which the preva- lence of enteric pathogens is high may be more resistant to developing $\operatorname{Re} A^{\prime \prime}$}

Secondly, although the number of subjects surveyed in the Kaslow paper is impressive, it is not known what the incidence of ReA would be in a similar number of Puerto Ricans exposed to $S$ flexneri. Populations in which exposure to enteric pathogens is high may be more resistant to developing ReA. Thus, in the International Centre for Diarrhoea Disease Research in Dhaka where more than 10000 cases of $S$ dysenteriae infection are seen annually, only one case of ReA has been described ${ }^{7}$-whereas one of the five Finnish patients with $S$ dysenteriae noted by Hannu et al developed ReA. ${ }^{1}$ In any case, the incidence of ReA following particular outbreaks of infection varies widely; for example, an outbreak in Fiji in 1897 had a $10 \%$ incidence of ReA whereas no cases occurred in a further outbreak in 1910 (observations of Mason-Bahr, quoted by Good ${ }^{8}$ ). Similar observations have been made in outbreaks of infection with Yersinia and Salmonella. ${ }^{9}$

Thirdly, it is possible that this Finnish survey detected cases which would not have been noted in previous investigations. Sensibly, in order to detect all possible sequelae of Shigella infection, Hannu et al used a broad definition of musculoskeletal symptoms-but with demonstrated specificity, because only 1 in 330 controls was positive by the same criteria, as compared with 18 of the 211 subjects infected by Shigella.

\section{WHEN DOES AN INFECTION INDUCE ReA?}

What factors determine whether infection with a particular organism induces ReA? When the idea was in the ascendancy that ReA might be due to immune responses which target epitopes common to the infecting organism and an autoantigen in the joint or enthesis (that is, molecular mimicry), apparent differences in the ability of closely related organisms (such as $S$ sonnei and $S$ flexneri) to cause ReA seemed to provide a possible way forward. In principle, one could identify the relatively small number of proteins which differed in the two organisms and screen these for candidate epitopes which would mimic self proteins. Thus, van Bohemen et al noted that certain monoclonal or polyclonal antisera directed against HLA-B27 cross reacted with a $20 \mathrm{kDa}$ protein present in $S$ flexneri but not in $S$ sonnei. ${ }^{10}{ }^{11}$ Likewise Stieglitz and Lipsky drew attention to a B27 mimicking epitope in the major plasmid of all strains of $S$ flexneri, but absent from $S$ sonnei. ${ }^{12}$

The observation that $S$ sonnei does indeed trigger ReA negates these approaches, and also the attractive hypothesis of molecular mimicry has not been borne out. ${ }^{13}$ Not that there are no examples of molecular mimicrymany have been described, involving antibodies and/or $\mathrm{T}$ cells-but it is unclear that any of these examples actually produce the disease in which they have been demonstrated. Indeed, molecular mimicry is almost inevitable given the number of epitopes in microorganisms and the likelihood that many of these will have human counterparts. It is now considered more relevant to determine how molecular mimicry is regulated so as to avoid immunopathology, rather than looking for particular examples of mimicry, because these will always be found if the search is wide enough.

\section{"S flexneri is a seriously delinquent E coli"}

Nevertheless, there must be particular properties of ReA triggering bacteria which allow them to induce the syndrome. Shigella illustrate this idea rather well; were Shigella to be discovered for the first time today, they would be classified as strains of $E$ coli, because the organisms are phylogenetically indistinguishable. Specifically, S flexneri shares all but 175 of 3235 open reading frames with two strains of $E$ coli. ${ }^{14}$ Self evidently, despite their similarity, the 
interactions of the two organisms with their human host are wildly different $-S$ flexneri is a seriously delinquent $E$ coli. The principal mechanisms which Shigella has acquired to induce disease are the ability to invade human enterocytes, lyse intracellular vacuoles to enter the cytoplasm, and move from cell to cell. $E$ coli does none of these things, and it is likely that the ability to survive intracellularly is critical to the causation of ReA, because this property is shared with Chlamydia, Yersinia, and Salmonella, though only Shigella has a cytoplasmic residence and moves from cell to cell.

\section{FACTORS DETERMINING THE INCIDENCE OF ReA}

Given that an organism has the ability to induce ReA, what determines the incidence of ReA in populations which become infected? There are likely to be several factors: some are stochastic, such as the infecting dose and, possibly, comorbidities such as subclinically inflamed joints (for example, weightbearing joints) to which organisms may traffic more readily within macrophages or neutrophils. ${ }^{15}$ Genes will also have a role-more ReA is generally found in populations with a high prevalence of HLA-B27-but other genes are likely play a part, including the extracellular and intracellular sensors of bacterial infection. These are the Toll-like receptors $^{16}{ }^{17}$ and CARD molecules, ${ }^{18}$ respectively. Mutations in CARD15 are associated with Crohn's disease, ${ }^{18} 19$ but not with ankylosing spondylitis ${ }^{20}{ }^{21}$; no studies of associations with ReA have yet been reported. The mutations alter the normal ability of CARD15 to control the responses to bacterial cell walls sensed by Toll-like receptor 2 on macrophages. ${ }^{22}$

Intracellular organisms have to take measures to prevent detection by the adaptive immune system, particularly CD8+ T cells. Shigella induces apoptosis of antigen presenting cells, although this may only result in enhanced presentation of antigens to CD8+ T cells when apoptotic cells containing bacteria are taken up by dendritic cells and the bacterial antigens "cross presented" on class I HLA molecules. Opportunities may occur for aberrant interactions between Shigella antigenic peptides and HLA-B27; studies have shown that the profile of peptides which can be eluted from cell surface HLA-B27 molecules changes drastically after infection with Shigella. More interestingly, several of the sequenced peptides which derive from Shigella proteins did not have the normal characteristics of B27 binding peptides, being longer than usual and not having arginine at position $2 .{ }^{23}$ Such peptides have previously been found to be associated with forms of HLA-B27 which lack $\beta_{2}$-microglobulin, ${ }^{24}$ though these forms can also bind the conventional peptides which are eluted from intact B27 trimolecular complexes. ${ }^{25}$ Whether unusual forms of B27, perhaps induced by intracellular infection, contribute to the immune responses which drive ReA is currently the focus of much debate. In any case, these ideas would correlate ReA with the intracellular niche occupied by Shigella and the effects on intracellular antigen processing, and this would apply equally to $S$ sonnei and Sflexneri.

Whether or not further investigation of ReA cases induced by Shigella infection will cast light on the pathogenesis of the arthritis, the practical point highlighted by the study of Hannu et al is clear: suspect Shigella as an inciting organism in patients with inflammatory arthritis recently returned from far off sunny climes, and look for it assiduously.

Ann Rheum Dis 2005;64:517-518.

doi: $10.1136 /$ ard.2004.030395

Correspondence to: J S H Gaston, University of Cambridge, Box 157, Level 5, Addenbrooke's Hospital, Cambridge CB2 2QQ;

jshg2@medschl.cam.ac.uk

\section{REFERENCES}

1 Hannu T, Mattila L, Siitonen A, Leirisalo-Repo M Reactive arthritis attributable to Shigella infection: a clinical and epidemiological nationwide study. Ann Rheum Dis 2005:64:594-8.

2 Kvien TK, Glennas A, Melby K, Granfors K, Andrup O, Karstensen B, et al. Reactive arthritisincidence, triggering agents and clinical presentation. J Rheumatol 1994;21:115-22.

3 Lauhio A, Lahdevirta J, Janes R, Kontiainen S, Repo H. Reactive arthritis associated with Shigella sonnei infection. Arthritis Rheum 1988;31:1190-3

4 Chen M, Delpech V, O'Sullivan B, Donovan B. Shigella sonnei: another cause of sexually acquired reactive arthritis. Int J STD AIDS 2002;13:135-6.

5 Simon DG, Kaslow RA, Rosenbaum J, Kaye RL, Calin A. Reiter's syndrome following epidemic shigellosis. J Rheumatol 1981;8:969-73.

6 Kaslow RA, Ryder RW, Calin A. Search for Reiter's syndrome after an outbreak of Shigella sonnei dysentery. J Rheumatol 1979;6:562-6.
7 Mazumder RN, Salam MA, Ali M, Bhattacharya MK. Reactive arthritis associated with Shigella dysenteriae type 1 infection. J Diarrhoeal Dis Res 1997;15:21-4.

8 Good AE. Shigellae and Reiter's syndrome. Ann Rheum Dis 1979;38(suppl 1):119-22.

9 LahesmaaRantala R, Toivanen A. Clinical spectrum of reactive arthritis. In: Toivanen $A$, Toivanen P, eds. Reactive arthritis. Boca Raton, FL: CRC Press, Inc, 1988

10 van Bohemen CG, Grumet FC, Zanen HC. Identification of HLA-B27M1 and-M2 crossreactive antigens in Klebsiella, Shigella and Yersinia. Immunology 1984;52:607-10.

11 Van Bohemen C, Nabbe A, Grumet F, Landheer J, Dinant $\mathrm{H}$, Zanen $\mathrm{H}$. Lack of correlation between HLA B27 like antigenic epitopes on Shigella flexneri and the occurrence of reactive arthritis. Clin Exp Immunol 1986;65:679-82.

12 Stieglitz H, Lipsky P. Association between reactive arthritis and antecedent infection with Shigellaflexneri carrying a 2-Md plasmid and encoding an HLA-B27 mimetic epitope. Arthritis Rheum 1993;36:1387-91

13 Benoist C, Mathis D. Autoimmunity provoked by infection: how good is the case for T cell epitope mimicry? Nat Immunol 2001;2:797-801.

14 Wei J, Goldberg MB, Burland V, Venkatesan MM, Deng W, Fournier $G$, et al. Complete genome sequence and comparative genomics of Shigella flexneri serotype 2 a strain 2457 . Infect Immun 2003;71:2775-86.

15 Granfors K, Jalkanen S, Toivanen P, Lindberg A. Bacterial lipopolysaccharide in synovial fluid cells in Shigella triggered reactive arthritis. J Rheumatol 1992;19:500.

16 Brightbill HD, Libraty DH, Krutzik SR, Yang RB, Belisle JT, Bleharski JR, et al. Host defense mechanisms triggered by microbial lipoproteins through toll-like receptors. Science 1999:285:732-6.

17 Cook DN, Pisetsky DS, Schwartz DA. Toll-like receptors in the pathogenesis of human disease. Nat Immunol 2004;5:975-9.

18 Ogura Y, Bonen DK, Inohara N, Nicolae DL, Chen FF, Ramos R, et al. A frameshift mutation in NOD2 associated with susceptibility to Crohn's disease. Nature 2001;411:603-6.

19 McGovern DP, van Heel DA, Ahmad T, Jewell DP. NOD2 (CARD15), the first susceptibility gene for Crohn's disease. Gut 2001:49:752-4.

20 van der Paardt $M$, Crusius JB, de Koning $M H$, Murillo LS, van de Stadt RJ, Dijkmans BA, et al. CARD1 5 gene mutations are not associated with ankylosing spondylitis. Genes Immun 2003:4:77-8

21 Ferreiros-Vidal I, Amarelo J, Barros F, Carracedo A, Gomez-Reino JJ, Gonzalez A. Lack of association of ankylosing spondylitis with the most common NOD2 susceptibility alleles to Crohn's disease. J Rheumatol 2003;30:102-4.

22 Watanabe T, Kitani A, Murray PJ, Strober W. NOD2 is a negative regulator of Toll-like receptor 2-mediated Thelper type 1 responses. Nat Immunol 2004:5:800-8.

23 Boisgerault F, Mounier J, Tieng V, Stolzenberg MC, Khalildaher I, Schmid M, et al. Alteration of HLA-B27 peptide presentation after infection of transfected murine $\mathrm{L}$ cells by Shigella flexneri. Infect Immun 1998;66:4484-90.

24 Urban RG, Chicz RM, Lane WS, Strominger JL, Rehm A, Kenter MH, et al. A subset of HLA-B27 molecules contains peptides much longer than nonamers. Proc Natl Acad Sci USA 1994;91:1534-8.

25 Malik P, Klimovitsky P, Deng LW, Boyson JE, Strominger JL. Uniquely conformed peptidecontaining beta 2-microglobulin-free heavy chains of HLA-B2705 on the cell surface. $J$ Immunol 2002; 169:4379-87. 